\title{
RUSSIAN PHILOSOPHERS OF THE SILVER AGE AS CRITICS OF MARXISM
}

\section{A. Walicki}

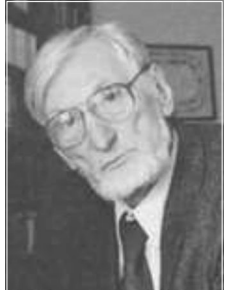

\section{Introductory Remarks}

$T^{t}$ is no exaggeration to say that in nineteenthcentury Russian thought the idea of progress was even more central and pronounced than in West European or American thought of the Victorian Age. Russian discussions about progress were especially passionate for a number of reasons, all of them connected with the specific nature and historical tasks of the Russian intelligentsia. To put it most briefly, we can distinguish three main causes of the peculiar intensity and richness of these discussions.

The first one is, obviously, Russian backwardness and the well-perceived, deeply felt need of modernization. In the absence of a modernizing bourgeoisie, after a series of disillusionments in the modernizing mission of the absolute monarchy ${ }^{1}$, the Russian intelligentsia - itself a product of modernization - came to see itself as the main vehicle of further progress. Its members, alienated from the ruling class and painfully aware of their inalienable responsibility for the fate of the "people" as well as for the position of their country in the family of civilized na- tions, enjoyed the cognitive "privilege of backwardness" [Gerschenkron, 1965:167170; Walicki, 1989:107-131], consisting in the possibility of learning from the accumulated experience of more-developed nations. This made them conscious not only of the humiliating backwardness of their country but also of the price and contradictions of European progress. Hence the characteristic tension between their enthusiastic devotion to the idea of progress and their bitter criticism of the really existing, "bourgeois" forms of modernization. A good illustration of this is provided by the Russian populists: all their ideas revolved around a "formula of progress" while containing, at the same time, a strong admixture of a backward-looking utopianism.

Another cause is the close interconnection between conceptions of progress and the question of national identity. Despite all the processes of westernization, nineteenth century Russia was very different from the European countries, and it was by no means obvious that these differences boiled down to the simple fact of backwardness: they could be interpreted as qualitative, culturally valuable, pertaining to a different type of national development. Hence the perennial dispute

\footnotetext{
1 The first disillusionment of Russia's intellectual elite with the modernizing autoc racy is symbolized by the name of "the first Russian intelligent," Aleksandr Radishchev. The next long step on this way was, of course, the Decembrist Uprising of 1825.
} 
between Russian Westernizers, adhering, as a rule, to a universalist and unilinear conception of progress, and many different advocates of a principled antiwesternism, stressing Russia's cultural distinctiveness, usually bound up with a spiritual superiority and a "special way" of her national development.

Finally, Russian discussions about progress expressed an intensive search for the meaning of history, which emerged as a result of the disintegration of Russia's ecclesiastical culture and served as a substitute for a religious world view [Zenkovsky, vol.1, 1953:70, 77]. Different Russian utopias of earthly salvation and the corresponding conceptions of progress represented, therefore, a secularization and historicization of the idea of the Kingdom of God. The peculiar eagerness with which the Russian intelligentsia committed themselves to the search for a "horizontal" (historical) collective salvation was, in a sense, the other side of their intolerance of the traditional Christian ideas of a transcendent Absolute and a "vertical," individual salvation in the afterlife.

A paradigmatic case of this intolerance was provided by the two "fathers" of the classical (i.e., leftist) Russian intelligentsia: Vissarion Belinskii and Aleksandr Herzen. The latter defined the "thinking Russians" as completely divorced from the past and, therefore, more independent, more radical than their Western counterparts, still paralyzed by the burden of inherited traditions. He was totally unable to understand the Polish revolutionaries who combined progressive ideas with religious faith, and he saw them for that reason as belonging, unwillingly, to the "old world"2.

It is useful to point out that the idea of progress had two functions in this secularized millenarianism. On the one hand, it showed the direction, thus giving an answer to the "cursed question" of what was to be done; on the other hand, it explained the necessity of a development through stages, thus justifying the evils of the past and present by reference to the meaningful pattern of historical evolution as a whole, paving the way to the earthly triumph of truth and justice. It contained the promise that the sufferings of the present would be fully compensated in the more or less remote epoch of the ultimate fulfillment of human destinies; hence the idea of progress performed the role of a justification of evil, that is, of a secular theodicy, or, rather, historiodicy. Even more than that, it contained also an argument for the view that the present had to be sacrificed for the future, that the presently living individuals, and entire generations, had to see themselves as mere instruments of universal progress [Kline, vol. 40, №2, 1986:215-235; Kline, 1989: 1-34]. The painful contradictions of Russia's historical development made this view both attractive and repellent: attractive as historical consolation, repellent as reconciliation with moral evils.

As can be seen from the above, the centrality of the idea of progress in nineteenthcentury Russian thought did not involve its universal, uncritical acceptance. The conception of progress as economic and social modernization found in Russia both enthusiastic advocates and powerful critics; very often these two attitudes toward modernization were combined somehow in the same thinker. The same is true about the idea of a universal, unilinear progress, allegedly common to all nations and identified, in practice, with the pattern of historical development of the West. And, most importantly for our topic, the same holds true of the idea of progress as a secular religion. The nineteenth - century Russian intelligentsia represented, no doubt, a peculiarly instructive exemplification of this phenomenon; at the same time, however, many of its members offered a passionate criticism of the "idolatry of progress." Suffice it to refer in this connection to Belinskii's and Herzen's revolt against the Hegelian conception of historical necessity, which justified the suffering of individuals in the name of universal progress ${ }^{3}$. A similar rejection of historio-

2 For a detailed analysis of this aspect of Herzen's "Russian socialism," see my Russia, Poland and Universal Regeneration (Notre Dame, IN: University of Notre Dame Press, 1989), pp. 39-69.

3 See Belinskii's letter to V.P. Botkin of 1 March 1844 (in Russian Philosophy, ed. J.M. Edie, J.P. Scanlan, and M.B. Zeldin with the collaboration of G.L. Kline, 3 vols. [Knoxville: The University of Tennessee Press, 1965], 
sophical theodicy can be found in Russian religious thinkers, particularly in Dostoevskii, who, as we shall see, powerfully influenced Russian philosophers of the Silver Age.

But let us turn now to the Russian reception of Marxism. At the end of the nineteenth century, Marxism became the dominant ideology of the Russian intelligentsia. Its widespread influence, as well as its initial tolerance by the authorities, was, in Lenin's words, "an altogether curious phenomenon": "Marxist books were published one after another, Marxist journals and newspapers were founded, nearly everyone became a Marxist, Marxists were flattered, Marxists were courted, and the book publishers rejoiced at the extraordinary, ready sale of Marxist literature [Lenin, vol.5, 1960-1970]."

There were many reasons for this interesting episode in Russian intellectual history. The authorities saw Marxism as a welcome antidote to populist terrorism and also as welcome intellectual support for government- sponsored industrialization. The intellectual elite saw it as the last word in European thought, offering a convenient way of combining conditional support for Russia's capitalist development (in the present) with continuous loyalty to socialism (as the final ideal). The Marxist theory of progress was hailed as a critical form of westernism, endorsing, in principle, the Western model of development but giving at the same time an unsurpassed critical analysis of the multiple contradictions of capitalist society. It was valuable for the elite as a respectable form of breaking with the legacy of populist socialism, such as the programmatic methodological "subjectivism" that undermined the authority of rigorous, "objective" scholarship, and the radical egalitarianism that was hostile to all forms of intellectual aristocracy.

It helped the Russian intelligentsia to overcome the deeply rooted populist prejudices against political freedom (as "bourgeois" in its class content and detrimental to "the common people"), thus legitimizing the struggle for it as a necessary phase of development. The Marxist endorsement of a capitalist economy and "bourgeois liberty" was, of course, qualified and relative; nevertheless, it was perceived as an important step toward the rehabilitation of political liberalism. This was not so in the case of Lenin, but in the 1890s Lenin's revolutionary and fundamentalist Marxism was still marginal and hardly visible. For the mainstream Russian intelligentsia, Russian Marxism was a current of thought having two intellectual leaders: Plekhanov in the emigration (publishing in Russia under the pseudonym "Beltov") and Petr Struve, head of the "legal Marxists," in St. Petersburg. Despite obvious differences (Plekhanov's dogmaticism and Struve's revisionism), both of them (in contrast to Lenin) proclaimed the need for "objectivism" in social science and for an alliance with the liberals in the struggle for political freedom ${ }^{4}$.

Philosophically, the common denominator of Plekhanov's and Struve's Marxism was a scientistic interpretation of history, stressing the deterministic, law-governed character of social processes and opposed to all forms of deontological, normative thinking. This fully agreed with the spirit of positivistic scientism and naturalistic evolutionism that became dominant in European thought in the second half of the nineteenth century 5 .

vol. 1, pp. 304 - 306) and Herzen's From the Other Shore, especially his famous words: "If progress is the end, for whom are we working? Who is this Moloch who, as the toilers approach him, instead of rewarding them, only recedes, and as a consolation to the exhausted, doomed multitudes crying 'morituri te salutant,' can give back only the mocking answer that after their death all will be beautiful on earth[?]" [Herzen, 1956:36].

4 Struve's article "Die Marxische Theorie der sozialen Entwicklung" (in Archiv fur soziale Gesetzgebung und Statistik, vol. 14 [Berlin, 1899] echoed Bernstein in its radical critique of the "utopian side" of Marxism. Lenin's early work "The Economic Content of Populism and Its Criticism in Mr. Struve's Book" (referring to Struve's Critical Remarks on the Economic Development of Russia, 1894) rejected Struve's "objectivism" in the name of a class standpoint in scholarship. It contained also an elaborate argument for the alliance with the peasantry and against the alliance with "bourgeois liberals."

5 Plekhanov, like Engels, tried to combine scientism and Darwinian naturalism with Hegelian dialectics. This led, of course, to a deep distortion of genuine dialectics. Nevertheless, this quasi-Hegelian component in Plekhanov's Marxism justified the search for a rational pattern and meaning in history, which was not quite 
The Russian intelligentsia took seriously the scientistic pretensions of Marxism and, consequently, saw historical materialism as the most consistent application of positivistic science to historical evolution. However, this intellectual situation changed with the appearance of the revolt against positivism in Europe. In Russia it began with transcendental (neo-Kantian) idealism, which established the autonomy of ethics without relapsing into relativistic "subjectivism," and soon developed into transcendent (metaphysical) idealism, which provided metaphysical grounding for the human personality and its inalienable rights. This, in turn, paved the way for openly religious philosophical thinking and the religio-philosophical renaissance in Russia. The former "legal Marxists" came to be the leading spirits in this intellectual revolution. As might have been expected, an important aspect of their philosophical development consisted in settling accounts with Marxism.

The present article deals with the criticism of Marxism by three representative thinkers of the Russian religio-philosophic renaissance: two former Marxists, Nikolai Berdiaev and Sergei Bulgakov, and Pavel Novgorodtsev, a leading figure in the revolt against positivism and the main theorist of the new, rights-based Russian liberalism ${ }^{6}$. However, I will not try to present and analyze Bulgakov's criticism of the Marxist economy or the successive stages in Berdiaev's and Novgorodtsev's struggle against positivism. I will concentrate instead on what I see as their most important contribution to a critical understanding of Marxism: namely, on their criticism of Marxism as a substitute for religion, that is, as utopia, not positive science. This focus appeared in their thinking when the antipositivist breakthrough in Russian intellectual culture was already an accomplished fact and when Marxism ceased to be merely an instrument of thought, becoming instead an all-embracing ideology of an organized revolutionary movement, characterized, especially in its Bolshevik version, by the single-minded fanaticism and crude fundamentalism of a millenarian crusade.

Nikolai Berdiaev. Lack of space does not allow for a comprehensive outline of Berdiaev's intellectual evolution here. Happily, such an outline is not absolutely necessary in the present context. Berdiaev's most important insights about revolutionary Marxism have been fully and forcefully expressed in a single article, "Socialism and Religion" (1906), written in the aftermath of the revolutionary events of 1905 in Russia."

In his other writings Berdiaev defined socialism as the inevitable and acceptable result of the "entire bourgeois development," a justified extension of the Declaration of the Rights of Man and of the Citizen [Berdiaev, 1907]. This applied, however, only to one type of socialism: the religiously "neutral" socialism, solving the problem of daily bread without pretending to replace religion [Berdiaev, 1990: 109]. Such socialism, represented by Proudhon, the British Fabians, and the liberal socialism of Bernstein, was opposed by the Russian thinker to another type of socialism - socialism as religion, represented by orthodox, revolutionary Marxism. This "religious socialism" was, in his view, "a complete dogma, a solution to the question of the meaning of life, the purpose of history" [Berdiaev, 1990:109]. It aimed at strict ideological control of all spheres of human activity, thus crushing freedom of conscience and allowing no room for spontaneously shaped personal identities. In other words, it was an ideocratic socialism, striving for an earthly salvation and, therefore, adamantly hostile to the idea of heavenly salvation ${ }^{7}$. Following Dostoevskii, Berdiaev defined this aspiration as a passion

consistent with naturalistic positivism. According to Ivanov-Razumnik, this peculiar feature of the Marxism of Engels and Plekhanov helped Russian thinkers to pass from historical materialism to philosophical idealism (Ivanov-Razumnik, vol. 2, 1908:450].

6 For a detailed presentation of Novgorodtsev's ideas, see chapter 5 of my Legal Philosophies of Russian Liberalism (Oxford: Clarendon Press, 1987; paperback edition published by the University of Notre Dame Press, 1992).

7 The term 'ideocracy' is not yet used in this article. Berdiaev introduced it in his later works, especially in The Origins of Russian Communism, where he defined 'ideocracy' as "pseudomorphosis of theocracy" ( Berdiaev, 1955: 137]. 
for the deification of man, a thirst "to organize this world not only apart from God but in opposition to him [Berdiaev, 1990:109].

In developing these views Berdiaev dwelled on three aspects of the Marxist religion: first, the element of crude theodicy, the justification of historical evils, including evil means for the realization of the final goal; second, the cold cruelty of its theory of progress, demanding a wholesale sacrifice of the present for the sake of an ideal future, treating presently living individuals as merely means for the future flourishing of the species; finally, "the poverty and wretchedness of its positive perspectives"[Berdiaev, 1990: 119] boiling down to the achievement of universal affluence and thereby subordinating all aspects of life to daily bread. Let us briefly discuss these three points.

The first two aspects, closely interrelated with each other, were indeed important features of Marxism. There can be no doubt that the author of Capital conceived progress as a long and cruel historical process in which not only individuals but also entire generations and classes had to be ruthlessly sacrificed for the sake of the unfettered development of the human species in the communist society of the future. He himself emphatically endorsed the "historical law" according to which the development of the capacities of the human species takes place at the cost of the majority of human individuals. The higher development of individuality is thus only achieved by a historical process during which individuals are sacrificed, for the interests of the species in the human Kingdom, as in the animal and plant kingdom, always assert themselves at the cost of the interests of individuals [Marx, vol. 2, 1969:118].

It is obvious that this conception of progress provided a convenient way of justifying past evils as necessary, unavoidable steps in historical development; suffice it to recall Marx's utter contempt for "sentimentalism," his apologia for the progressive role of slavery (including nineteenth- century American slavery) ${ }^{8}$ or his emphatic assertion of the necessary and ultimately progressive function of the atrocities of primitive accumulation. He did not hesitate to state that historical progress in the past had nothing in common with the increase of humanitarianism: it resembled rather "that hideous pagan idol who would not drink the nectar but from the skulls of the slain". And it is evident that he attributed to evil passions the role of prime movers of progress not only in the past but also in the immediate future - after all, he made the victory of socialism dependent on the intensification and mobilization of class hatred, not on its gradual disappearance from human relations. Using the terminology of Nietzsche, we can say that "the love of the remote" (Fernstenliebe) - that is, the love of the imagined communist humanity - made Marx conspicuously indifferent to the fate of the imperfect human individuals of the capitalist present [Marx, 1985:336]. Berdiaev was therefore right in accusing Marxism of justifying cruelty and treating everything as merely a means for the future [Berdiaev, 1990:112].

Berdiaev's sensitivity to this aspect of Marxism was increased by his awareness of the distinctively Russian tradition of criticizing the idolatry of progress. He was influenced by N.K. Mikhailovskii, a thinker who passionately rejected the Marxist notion of historical inevitability and referred in this connection to Belinskii's rejection of the "rational necessity" in Hegelianism". He quoted Ivan Karamazov's rebellion against historiosophical theodicy - his refusal to accept the future harmony, if purchased by the sufferings of the innocents. His (Berdiaev's) reference to the "bad infinity of progress," as leading to slavery in time to the cycle of birth and

8 In his letter to P.A. Annenkov of 28 December 1846, Marx wrote: "Without slavery North America, the most progressive country, would be transformed into a patriarchal land. You have only to wipe North America off the map of the nations and you get anarchy, the total decay of trade and of modem civilization. But to let slavery disappear is to wipe North America off the map of nations" (K. Marx and F. Engels, Selected Works, 3 vois. [Moscow: Progress Publishers, 1977], vol. 1, p. 524).

9 Berdiaev was well acquainted with Mikhailovskii's ideas because his first book, Sub'ektivizm i individualizm v obshchestvennoi fdosofti (published in St. Petersburg in 1900), was devoted to Mikhailovskii's social philosophy. Belinskii, especially as a critic of Hegelian historiodicy, was one of Berdiaev's favorite thinkers. 
death, reminds one of the views of Nikolai Fedorov, who treated progress as an immoral idea, involving the dismissal of past generations as mere stepping-stones to the happiness of future ones.

But the most important factor influencing Berdiaev's attitude toward Marxism was his careful observation of the Bolsheviks. Their militancy, ideological fundamentalism, and unswerving devotion to the final goal sharply contrasted with the advances of revisionism and the rapid de-eschatologization of Marxism in German social democracy. Hence, Russian bolshevism offered a much better perspective for the understanding of Marxism as a horribly brutal (Berdiaev's expression) "religion of progress [Berdiaev, 1990:114]. It was Berdiaev's merit to realize this and to predict that the victory of revolutionary Marxism in Russia would lead to totalitarian slavery [Berdiaev, 1990:129].

I fully realize that this conclusion is not convincing for all those who believe that German social democracy was more faithful to the original spirit of Marxism than Russian bolshevism. Such a view, however, is very superficial and misleading. Berdiaev's interpretation presupposes a clear distinction between Marxism as science and Marxism as the secular religion of communism ${ }^{10}$; if we accept this valid distinction, we have to concede that the development of German social democracy after Engels's death consisted in a gradual but steady abandonment of Marxist communism ${ }^{11}$ while Russian bolshevism remained fanatically faithful to it. Abandoning Marxist communism should not be seen as developing it, as being its legitimate heir. Hence, it is justified to say that Marxist communism - that is, Marxism as a "religion" was being betrayed by German social dem- ocrats; this made the party of Lenin more representative of the original Marxism than the party of Kautsky.

Berdiaev's third point is somewhat less well taken. There is a certain contradiction in his view of Marxism's final goal. On the one hand, he saw in Marxism the potential for a new religion of superhumanity, that is, "the striving toward a new earthly God who will emerge at the end of progress and in whose name all humanity itself is transformed into a means [Berdiaev, 1990:112113]". On the other hand, he saw Marxist religion as superficial, as nonradical in its content, subordinating everything to the petty-bourgeois ideal of universal material security - an ideal whose realization would transform people into "millions of happy infants. The first diagnosis was inspired by Nietzsche's vision of the superman, as well as by Dostoevskii's analyses of the hubris of the omachist atheism; the second took up the vision contained in Dostoevskii's "Legend of the Grand Inquisitor." In Berdiaev's view these two diagnoses were interconnected because the Promethean ideal of the deification of man was ultimately selfdefeating, bound to usher in the utter degradation of humanity. Nevertheless, quite irrespectively of our view of the value and logical coherence of this interpretation, he should have been more clear about the basic intention behind the Marxist religion [Berdiaev, 1990:122-123.]. Was it a striving for a regenerated, godlike humanity, or merely a desire to subordinate everything to the prosaic question of daily bread?

The discovery and publication of the works of the young Marx, especially his Economic and Philosophic Manuscripts of 1844, made it evident that Marx's ultimate concerns cannot

\footnotetext{
10 It is now obvious that Marxism as a scientific method, that is, as historical materialism, does not involve commitment to Marxism as communist utopia. Some of the best Marxologists (J.Y. Calvez in France, Stanley Moore in the United States) have rightly pointed out that there is a tension between Marxism as an allembracing theory of communism and Marxism as historical materialism. The latter deals with historical processes as made by humans but not designed by them-in other words, it is a theory of the unintended results of human action, of creating history within the structure of alienation, without the possibility of controlling its course. In contrast with this, Marx's theory of communism presupposes conscious steering of historical processes, assuming, therefore, that consciousness would no longer be determined by life, that men would be not only actors in but also authors of their history. For an elaboration of this distinction, see [Calvez, 1956: 533-534; Moore, 1980: 18, 90].

11 The most notable exception to this was, of course, Rosa Luxemburg.
} 
be reduced to the question of daily bread. Unlike the system of Dostoevskii's Grand Inquisitor, Marx's communism was about freedom rather than bread: freedom conceived as conscious mastery over collective fate, putting an end to alienation and thus bringing about a tremendous increase of human species powers, a truly unheard of, unimaginable feast of universal liberation.

Communism so conceived was to be nothing less than "the solution of the riddle of history," the true solution of "the struggle between existence and essence, between objectification and self-affirmation, between freedom and necessity, between individual and species. [Marx, 1985:89]". It was to create a new race of people, superior to the present generation not only spiritually but physically as well. Young Marx boldly proclaimed the idea of a "complete emancipation of all human senses and qualities": the eyes and ears of the de-alienated people of the future will be completely different from the crude, inhuman eyes and ears of the dehumanized people of the present [Marx,1985:92 ].

We can see, therefore, that Marx's early writings supported Berdiaev's first diagnosis (the "religion of superhumanity"). Marx's "people of the future" were to be supermen, not "happy infants." This was clearly realized by sophisticated representatives of the militant wing of Russian Marxism. A telling testimony of this is Trotskii's vision of the communist man - totally transformed, capable of changing and controlling not only the social but also the biological life of the species. Under communism, he wrote, "man will become immeasurably stronger, wiser and subtler; his body will become more harmonized, his movements more rhythmic, his voice more musical. The average human type will rise to the heights of an Aristotle, a Goethe, or a Marx [Trotsky, 1966:256]"

It is easy to see, however, that this final ideal could serve as a justification of the most brutal totalitarian tyranny. Trotskii exemplified this in his Terrorism and Communism, written in 1920, providing arguments for slave labor and the total militarization of life in the transitional period. He said explicitly that the dictatorship of the proletariat represented "the most ruthless form of state, which embraces the life of citizens authoritatively in every direction [Trotsky, 1986:170].

This was a perfect confirmation of Berdiaev's view that Marxist communism would call into being the most unrestricted state despotism and thus establish "the definitive and final slavery». On the whole, Berdiaev's analysis of Marxism deserves the close attention of Marxologists [Berdiaev, 1990:128-129]. It has not become antiquated; on the contrary, it can serve as an indispensable reminder of those features of Marxism that are, as a rule, conveniently forgotten. After the "discovery" of the young Marx, hundreds of authors, not necessarily Marxists, triumphantly argued that Marx, as was evident from his early writings, had always been a great humanist and libertarian, seeing the highest end in the unfettered, non-alienated development of individual human beings.

What was forgotten, or deliberately ignored, was the simple fact that, according to Marx, the principle of treating human beings as ends in themselves was valid only under communism, that is, only at the final stage of progress; before the attainment of this stage the human individual was to be treated as "never a goal and always a means [Berdiaev, 1990:112]. Remembering this effectively destroys all attempts to present Marxist communism as a form of radicalism that had nothing in common with totalitarianism and was compatible with the principles of modem democracy.

Sergei Bulgakov. Another ex-Marxist, the future Orthodox theologian Sergei Bulgakov, developed similar ideas but with a different emphasis. Like Berdiaev, he perceived Marxism as the last word in nineteenth-century theories of progress and, at the same time, as a surrogate of religion - the religion of positivism, combining scientistic pretensions with the ability to impart meaning to history and thus to satisfy an ineradicable human need [Bulgakov, 1903:ix].

Unlike Berdiaev - or, at least, unlike Berdiaev as the author of "Socialism as Religion" he stressed the attractiveness of this "religion of millions" [Bulgakov, 1903:122] and did not try to set against it the religiously "neutral" type of socialism. On the contrary: at the first stage of his evolution toward idealism he 
continued to value Marxism precisely as a doctrine with a utopian and eschatological dimension, powerfully attractive for "religiously minded atheists [Bulgakov, 1903:ix-x]".

The religiously "neutral" evolutionary socialism of Bernstein represented, in his view, a degraded form of Marxist thought - Marxism without wings [Bulgakov, 1903:ix-x]. He was alarmed by the successes of Bernsteinian revisionism and saw them as a symptom of the inevitable de-utopianization and de-eschatologization of Marxism. As a religiously minded man he did not welcome this development: Marxism without the faith in "the leap to the kingdom of freedom" was for him unworthy of allegiance. He reacted by concluding that the Marxist combination of positivistic science with religious mentality proved no longer workable, that science ceased to support the belief in the meaning of history, and, therefore, that to save this belief it was necessary radically to separate religion from science [Bulgakov, 1903:ix-x]. This diagnosis motivated his turn toward metaphysical idealism and theistic religiosity.

Thus, Bulgakov's religious philosophy emerged, partially at least, as a reaction to Bernsteinian revisionism, that is, as a reaction to the seeming disappearance of the Marxist religion, not (as in Berdiaev's case) to its inherent falsity. This does not mean that Bulgakov was insensitive to the inner contradictions and morally unacceptable aspects of the Marxist "religion of progress." There is no reason to doubt that he was increasingly aware of them. Like Berdiaev, he was well acquainted with the Russian tradition of criticizing the idolatry of progress; he devoted to it two important articles: one on Herzen, another on Dostoevskii's Ivan Karamazov. But the fact remains that he wrote these articles in the first two years of the new century, that is, at the time when his Marxist faith had already been destroyed by Bernstein.

Bulgakov's article on Dostoevskii is philosophically more important than his article on Herzen and deserves a short summary in the present context. Its relevance for our topic derives from Bulgakov's practical identification of the theory of progress with socialism, and socialism with Marxism. Socialism, he wrote, was historically the most important, as well as the most widely accepted, theory of progress [Bulgakov, 1903: 105] Marxism was, of course, the most important socialist theory; hence Ivan Karamazov, as a passionate critic of the theory of progress, was simultaneously a critic of socialism and in particular a critic of Marxism. He was, as Bulgakov put it, a "skeptical son of the epoch of socialism [Bulgakov, 1903:109].

The expression "epoch of socialism" may seem strange in its application to the nineteenth century. Bulgakov meant by this the centrality of the socialist idea in nineteenthcentury intellectual life and popular expectations. In this sense socialism provided the frame of reference for all theories of progress and all future-oriented historiosophies of this century. Even Nietzsche, with all his hostility toward socialism, was "a product of the socialist world view, its illegitimate spiritual son [Bulgakov, 1903].

Ivan Karamazov dared to challenge the main dogmas of the nineteenth- century religion of progress. He did so by questioning the principle of "living for the future," by rejecting the price of progress as too high, as morally unacceptable, and, finally, by putting in doubt the value of universal happiness as the final goal of history [Bulgakov, 1903:105-106]. Bulgakov endorsed these doubts, presented them as his own, and concluded that the problems of historiosophical theodicy could be solved only through a metaphysical and religious synthesis [Bulgakov, 1903:98]. Nevertheless, he refrained from rejecting socialism as such, limiting himself to saying that materialism and positivism were unable to mobilize ethical enthusiasm, necessary for the realization of socialist ideals. Did this mean that a Christian socialism, which became his own ideological option [Putnam,1977] would be more justified in demanding human sacrifices than the atheistic socialism? Unfortunately, Bulgakov's article did not provide an answer to this question; it remained somewhat unclear whether the principle of sacrificing the present for the future should be rejected or merely softened by promising celestial rewards for the sufferers.

Bulgakov's most important text about Marxism was his pamphlet Karl Marx as a Re- 
ligious Type, published for the first time as a newspaper article in 1906. It was no longer a study of Marxism as the best exemplification of something broader, more general - socialism as such, or the theory of progress - but a study of ideas and attitudes characteristic of a single individual named Karl Marx. And it was intended as Bulgakov's final attempt to settle accounts with the thinker who had so deeply influenced him in the past [Bulgakov, 1990: 311].

Karl Marx, Bulgakov argued, was by no means an attractive individual. Love of one's neighbor or spontaneous sympathy and compassion for other humans were almost unknown to him. He was a "dictatorial type," motivated mostly by negative feelings, such as hatred, anger, envy, and contempt for all those who dared to disagree with him. Consequently, his polemical style was utterly aggressive, vituperative, trying to crush the adversary and to intimidate his followers. He thought in abstract, sociological terms and showed no interest in the concrete and the individual, no understanding of the absolute value of the irreducible human personality, and no concern for its fate. Hence he would have been unable to understand Ivan Karamazov's protest against the cruel aspects of the theory of progress [Bulgakov, 1990: 313314, 317].

In his analysis of Marx's ideas, Bulgakov relied on his interpretation of Marxism as an atheistic religion, deeply hostile to theistic religion, especially Christianity. The new elements in his interpretation consisted in concentrating on the philosophical sources of Marx's thought, on the importance of his early works, and on the differences between the Marxism of Marx and the official Marxism of German social democracy. This new emphasis was made possible by Mehring's publication of some works of the young Marx in 1902.53

Careful reading of Marx's two articles of 1843 -1844 - "On the Jewish Question" and "Toward a Critique of Hegel's Philosophy of Right" - led the Russian thinker to conclude that these early writings contained Marx's "philosophical maximum" and provided the best key to the understanding of his world view [Bulgakov, 1990: 336]. At the same time, however, Bulgakov saw in them a decisive argument against the popular view of Marx's indebtedness to Hegel. Marx, he asserted, had never been a philosophical idealist; hence, he could not have been a disciple of Hegel. His true philosophical teacher was Ludwig Feuerbach. Marx's historical materialism was in fact little more than a translation of Feuerbachianism into the language of political economy [Bulgakov, 1990:338]. Hence it was justified to say that Feuerbach was the untold secret of Marx, as well as the solution of this secret [Bulgakov, 1990:326].

This conclusion corroborated Dostoevskii's thesis that socialism, as the modem variant of humanistic atheism, aimed above all at the replacement of the religion of Godmanhood by that of Mangodhood - that is, by the deification of humanity. Bulgakov cautiously added that Marx took up the critical side of Feuerbach's philosophy without following him in the explicit commitment to the ideal of deification of the human species. Nevertheless, he found in Marx's early writings an unmistakenly Feuerbachian conception of man's ultimate liberation: a conception of liberating people from their "egoism" through transforming them into "species beings," or "communal beings," free from the alienating pluralism of the conflicting interests of civil society and capable of merging together in unanimous community. He discovered these views - the notion of "species being" (Gattungswesen) and the total rejection of pluralistic civil society - in Marx's article "On the Jewish Question." His comment on this article deserves to be quoted:

- $\quad$ it is easy to fmd here Feuerbach's idea about Gattungswesen, about the human species as the highest instance for man. In Marx this "love of the remote," for the not -yet- existing humanity of the future, takes the form of an outright contempt toward "one's neighbor," that is, really existing human beings;

- $\quad$ thus, only when people lose their individuality and society transforms itself into a Sparta, an ant-hill, or a beehive - only then will the task of human emancipation be complete;

- in other words, Bulgakov interpreted Marx's essay as a manifesto of collectiv- 
ism, demanding the complete socialization of man. He saw this as the gist of Marx's utopia, the heart of Marxism as an integral, all- embracing world view.

In the remainder of his study Bulgakov reflected on the relationship between this world view and the Marxist teachings of the theorists of German social democracy. He stressed that the German workers' party was created by Lassalle, that its commitment to Marxism (whether its theorists were aware of this or not) was never total, and that its development in recent years consisted in gradual liberation from Marxist dogmas.

Showing the vital connection between Feuerbach and Marx was a strong side of Bulgakov's interpretation. It is true that Marx's critique of capitalism started "from the account of human nature set forth in Feuerbach" and that his philosophical communism was based on Feuerbach's conception of man as Gattungswesen [Moore, 1980:9]. In 1906 this aspect of Marxism was almost completely ignored and stressing it was an important contribution. However, it was a great exaggeration to conclude from this that Marx owed nothing to Hegel. In fact, he borrowed from Hegel the central idea of the dialectical conception of the self-actualization of human "species being" in history - the idea of selfenriching alienation [Wlacki, vol.2,1988:1058].

True, Marx's Economic and Philosophical Manuscripts were published only in 1932, and without this text it was impossible fully to reconstruct Marx's theory of alienation. Nevertheless, Bulgakov too hastily dismissed the significance of Hegel for Marx's thinking. After all, Hegelian dialectics underlay Marx's account of the development of man's "species being" and was, therefore, inseparable from his "Feuerbachianism." Bulgakov's utterly negative view of Marx's dialectics stemmed probably from its unconscious identification with the naturalistic distortion of dialectics in the works of Engels [].

Focusing on Marx's final goal (and not merely his theory of progress) was another merit of Bulgakov's interpretation, sharply distinguishing it from the dominant "scientific" accounts of Marxism. Bulgakov was right in emphasizing that the Marxist "science" contained a soteriological myth, a quasi-millenarian religion of earthly salvation [Bulgakov, 1990:341].

However, strangely enough for a professional economist, he did not define the economic content of Marx's final ideal; he failed to see that Marx's conception of human emancipation involved a wholesale abolition of the market economy, as generating the divisive pluralism of conflicting interests and thus preventing the actualization of man's communal essence. In addition, his criticism of Marxist secular millenarianism stopped short of rejecting millenarianism as such. On the contrary: at the end of his study he quoted from the Lord's Prayer, interpreting the words "Thy Kingdom come" as tantamount to stating that the Kingdom of God on earth was the final end of human history.61 He even expressed a hope that Marxist socialism, as opposed to Marxism as a religion, might prove to be working for the realization of this Kingdom [Bulgakov, 1990:341-342].

Such inconsistency characterized Berdiaev as well. In 1906, reacting to revolutionary violence, he pointed out the heretical nature of millenarian dreams, declaring that the eschatological dimension of Christianity should not be understood as salvation in history [Berdiaev, 1906:390]. In the next year, however, resisting the statist spirit of "Stolypin's reaction," he embraced the idea of "anarchist theocracy" and proclaimed genuine socialism - that is, socialism free from both the omachist revolutionism and Bernsteinian "bourgeois philistinism" - to be a right step in this direction: its task was to permeate the economic sphere with the divine spirit and thus to provide an economic foundation for the Kingdom of God [Berdiaev, 1907:113, 122-129].

Pavel Novgorodtsev. Novgorodtsev, head of the Moscow school of legal theory, was the first thinker of the Russian religio-philosophical renaissance who elaborated a consistent philosophical critique of all variants of teleologically conceived progress. He saw them as secularized versions of millenarianism but did not concentrate exclusively on their analogy with religious thinking. His frame of reference in analyzing them was, the problem of the social ideal and of the utopian be- 
lief in a paradise on earth ${ }^{12}$. In approaching this problem, he combined Kant's criticism (ideals as regulative guides, not goals to be fully realized in history) ${ }^{13}$ with a religious perspective, critical of the immanentization of the Absolute as involving the mortal sin of idolatry. He followed also Trubetskoi's analysis of Solov'ev's theocratic utopia, endorsing the view that the error of utopianism consisted in the absolutization of the relative, that is, in attributing absolute significance to certain relative values and thus paving the way for the tyranny of false Absolutes [Trubetskoi, vol. 1, 1913:111, 564-584]. In opposing all conceptions of an immanent meaning of history in the name of a nontemporalized, transcendent Absolute, he anticipated, to a great extent, Voegelin's warnings against "immanentization of the eschaton [Voedelin, 1987:119-120].

Almost half of Novgorodtsev's book On the Social Ideal (1917) is devoted to Marx and the historical fate of Marxism. It was not just another polemical writing but a scholarly contribution to Marxology. Its originality consisted in concentrating not on Marxist science but on the Marxist utopia. This was, of course, very different from the established views on "scientific socialism" and especially from the self-image of the German Marxists of the Second International. In the context of the Russian religio- philosophical renaissance, Novgorodtsev's originality was less striking because he was partially dependent on Bulgakov, whom he often quoted in his book. Like Bulgakov, he interpreted Marxism as the most perfect specimen of a religion of earthly salvation, deriving from the Feuerbachian conception of the immanent divinity of humankind; a religion without transcendence, seeking salvation in absolute collectivism, in reuniting individuals with the species through raising them to the level of species beings ${ }^{14}$.
Following Bulgakov, Novgorodtsev paid special attention to the works of the young Marx, especially his essay "On the Jewish Question." He focused on Marx's criticism of the rights of man as rights of egoistic individuals, asserting themselves against the community and thereby denying man's "communal essence." He rightly derived from this Marx's hostility to the law-governed state (pravovoe gosudarstvo), as sanctioning the divisive egoism of the civil society, and Marx's utopian vision of the "withering away of law and the state" in the communist society of the future [Novgorodtsev, 1991:119-120]. But he did not question Marx's view of the relationship between the law-governed state and modem individualism.

His disagreement with Marx concerned value judgments rather than facts. He used Marx's diagnosis as an indirect corroboration of the liberal view of the positive role of the modem, law-based state in the emancipation of the individual. He fully agreed that the total socialization of man would involve the disappearance of law and the state, but he refused to see this as the desired end of human history. The abolition, or withering away, of law and the state would leave no room for personal autonomy; people would be transformed from individualized beings into species beings. Marx, Novgorodtsev commented, "saw this as the absolute human emancipation. As a matter of fact, this would be the absolute subordination of individual to society. In the Marxist philosophy there is no place for a genuine idea of personality; hence, there is no room for personality in the Marxist ideal [Novgorodtsev, 1991:271].

Among the writings of the "mature Marx," the most revealing for an understanding of the Marxist utopia was, of course, "The Critique of the Gotha Program." In analyzing it, Novgorodtsev agreed with Marx that "right

\footnotetext{
12 He devoted to this problem a series of articles in Voprosy filosofii i psikhologii over the years 1911-1917. (Collected in book form as Ob obshchestvennom ideale, revised 1922).

${ }^{13}$ For an excellent formulation of the programmatically antichilias tie and anti- ucopian tendency $m$ Kant's philosophy, see [Kelly, 1969:14-15, 127-131].

14 P.I.Novgorodtscev was even more consistent than Bulgakov in interpreting Marxism as a further development of Feuerbachianism; he criticized Bulgakov for his statement than Marx took up only the «critical side» of Feuerbach,s philosophy, claiming that in fact Marx embraced also Feuerbach,s philosophy «antropotheisme» See: [Novgorodtscev, 1991:146,214-218]
} 
by its very nature can consist only in the application of an equal standard" and, therefore, that every right is inevitably "a right of inequality [Marx, Engel s, vol.3, 1977:18]. He saw these words as an expression of the realistic side of Marx's world view and, at the same time, as a good explanation of the radical incompatibility between the juridical point of view and Marx's utopianism. On the one hand, Marx had acknowledged that individuals were unequal, that they "would not be different individuals if they were not unequal, [Novgorodtsev, 1991:119-120] and, therefore, that they were bound to think in terms of "rights"; on the other hand, Marx's ideal of the higher stage of communist society presupposed the overcoming of "the narrow horizon of bourgeois right" and of the standpoint of "right" as such [Novgorodtsev, 1991:119]. If so, Novgorodtsev argued, the realization of Marx's ideal meant, in practice, that people would cease to feel themselves as different individuals, becoming instead species beings, renouncing any appeals to right and justice, surrendering their freedom to the supraindividual life of the species [Novgorodtsev, 1991:321].

Another feature of Marx's utopianism was its striving for the wholesale rationalization of social life [Berdiaev, 1990:124]. In this respect Marx's and Engels's attitude toward law and the state was diametrically opposed to Stimer's anarchistic irrationalism [Novgorodtsev, 1991:315]. In contrast to Stimer, the founders of Marxism criticized law and the state as institutions sanctioning egoistic individualism and therefore creating obstacles to the complete rationalization of social life. Their ideal of freedom was utterly collectivist and rationalist, conceiving freedom as conscious rational control over the conditions of life and development of the species - that is, as conscious planning and a perfect rational order. Their visi on of "the leap from the kingdom of necessity to the kingdom of freedom" [Marx, Engels, vol.3, 1997:150] identified freedom with conscious, planned regulation and necessity with irrational spontaneity.
Novgorodtsev had no doubts that a realization of such a vision would lead in practice to the maximum centralization of power and to the subordination of all spheres of individual life to the arbitrary will of those in power [Novgorodtsev, 1991:321].

Awareness of the authoritarian dangers inherent in the communist ideal turned Novgorodtsev's attention to the problem of Marx's attitude toward democracy. He agreed with Bernstein that Marxism was compatible with both democracy and dictatorship, owing to the lack of sharp contrast between these two notions in Marxist theory [Novgorodtsev, 1991:302-303]. The dictatorship of the proletariat was, in Marx's view, a form of dictatorship and a form of democracy at the same time. Novgorodtsev was one of the first thinkers who subjected Marx's teaching about the dictatorship of the proletariat to a close analysis, pointing out the possibility of its different interpretations. He even claimed the priority in this respect, since he dealt with Marx's conception of politics in the transitional period already in the first edition of his book (1917), that is, before the appearance of the most important works on this subject [Novgorodtsev, 1991:274].

At the top of the short list of these works Novgorodtsev put Lenin's book The State and Revolution (1917); the second place he gave to Hans Kelsen's Sozialismus und Staat (Leipzig, 1920) ${ }^{15}$. Lenin's book, in his view, deserved attention as a "detailed enumeration of almost all passages from the works of Marx and Engels that deal with the state;" its main shortcoming was leaving out of account Marx's essays of 1844 ("Zur Kritik der Hegelschen Philosophie" and "Zur Judenfrage") and Engels's "revisionist" introduction to Marx's Class Struggles in France of 1895 [Cunov, 1920:27]. This shows that he valued this book mostly as a useful collection of quotations. In the footnotes to the new edition of $\mathrm{Ob}$ obshchestvennom ideale, he took issue with some of Lenin's interpretations of the meaning of the quoted passages. But, amazingly, he failed to discuss Lenin's work as a whole, as a mani-

15 Two other book mentioned in this contex twere F. Mauthner der Bolsschevismus, seines Verhaltnisses zum Marxismus (Berlin, 1920); H. Cunow Die Marxishe Geschichts gessellshafts und Staatstheorie (Berlin, 1920). 
festo of militant communism, consciously and adamantly opposed to the social- democratic Marxism of the Second International. In his detailed, analytical account of the history of the workers' movement, he concentrated on Germany and France, completely ignoring Russian Marxism, bolshevism, and the Russian revolution.

The limitation of the scope of analysis allowed Novgorodtsev to arrive at very optimistic conclusions. German Marxism had split into reformist and revolutionary currents; the former had already abandoned its utopian faith in ultimate salvation on earth, embracing instead the idea of a law- based, democratic national state; the latter was bound to do the same under the threat of becoming discredited and rejected. This meant that Marxism as a total world view was dead and beyond resurrection [Cunov, 1920:27]. But, Novgorodtsev added, it was dead only in its revolutionary and utopian strivings, not as an effort to improve the lot of the working people [Cunov, 1920:419]. Its "vital truth" was the idea of man's right to a dignified existence, and this ideal became assimilated by the modem, socialized liberalism and the modem law-governed state.

True, this idea was not specifically Marxist, and not even specifically socialist: it was formulated in the process of the organic development of liberal thought. Nevertheless, it was Marxism that necessitated its practical implementation. "We must recognize," Novgorodtsev argued, "that Marxism marks a point after which moral consciousness cannot return to the past, after which the modem law-governed state had radically to change its views on the tasks of politics, on the nature of law, and on the principles of equality and freedom [Cunov, 1920:522, 521]. Therefore, the death of Marxism as a utopia of earthly paradise could not entail the death of its "indisputable truth," its "vital kernel," which constituted the heart of all socialist teachings of the past and which Marx had felt, understood, and expressed with unusual force [Cunov, 1920:522].

It is somewhat strange that Novgorodtsev's book ended on this note. It was not consistent with his analysis of Marxism, which showed that the heart of Marxism was pre- cisely its utopian dimension, permeating all aspects of Marx's thought [Cunov, 1920:217], that "scientific socialism" was in fact not a scientific overcoming of all utopianism but the most widespread and intense utopian faith of modem times. It contradicted his brilliant interpretation of Marx's and Engels's vision of the revolutionary "leap to the kingdom of freedom," which uncovered the logical hiatus between the conception of necessary, objective laws of history and the ideal of liberating people from their yoke through establishing an effective, conscious direction of historical processes [Cunov, 1920:221-222]. In particular, it contradicted his revealing analysis of the problem of law and the state in Marxism - an analysis that established beyond doubt that Marxism had nothing in common with thinking in terms of "rights" and with the intention to contribute to the development of the law - governed state.

Novgorodtsev's conclusions were based upon his close study of the fate of Marxism in Germany. His presentation of the history of German social democracy was excellent, but it is not quite clear why he chose to treat this history as a sufficient basis for broad generalizations about the death of Marxism. After all, his own analysis has shown that the intellectual heritage of the German Social Democratic Party was not homogeneously Marxist and that the evolution of its ideology consisted in fact in the gradual renunciation of Marxist tenets, in the gradual abandonment of Marxism both as a "science" and (even more) as a communist utopia [Cunov, 1920:395]. If so, the increasing commitment of German social democrats to democracy and the rule of law should not be treated as providing an insight into the essential truth of Marxism. And the death of Marxist communism in Germany should not be seen as tantamount to the death of Marxist communism in general. If Marxist communism wqs dead in Germany, it did not follow that it was dead in Russia.

The third edition of Novgorodtsev's book was published after the Bolshevik revolution; after Lenin's rejection of the compromised name "social democracy" and his proud proclamation that now his own party, calling itself "Communist," was the only legitimate successor of the entire legacy of genuine Marx- 
ism; after the Bolshevik experiment with war communism, an exercise in revolutionary utopianism directly inspired by the Marxist idea of a "leap to the kingdom of freedom." Novgorodtsev, however, did not take these events into account. He was uniquely equipped to interpret the Bolshevik revival of Marxist utopianism, but he failed to undertake this important task.

The same is true of Bulgakov, who at that time ceased to be interested in Marxism. His interpretation of Marxism was less rich than Novgorodtsev's but was on the whole similar. Both thinkers had the merit of drawing attention to the texts of the young Marx; both - in sharp contrast to the later phenomenon of the Western reception of the "early Marx" - interpreted these texts as the expression of an adamantly antiliberal "absolute collectivism"; both concentrated on the quasi-religious function of the Marxist "science" and on the presence of a powerful utopian drive in Marxist thought. At the same time, both were rather insensitive to the economic aspect of Marxist utopianism: both insisted on the positive side of socialist reforms and remained silent about the dangers of the communist idea of a total suppression of the market economy. Finally, both had grossly underestimated bol- shevism as the possible successor of Marxist revolutionary communism.

Many features of Bulgakov's and Novgorodtsev's vie $w$ of Marxism were present also in Berdiaev's conception of "socialism as religion." Berdiaev can be credited with a greater awareness of the vitality of the revolutionary, militant trend in Marxism and with a prophetic insight into the nature of its "ideocratic" aspirations. Nevertheless, he also failed to produce an interpretation of bolshevism as the most consistent version of militant Marxism. His well-known explanations of the Russian Revolution revolved around the problem of its distinctively Russian roots, thus turning attention away from the continuity between Lenin and the founders of Marxism.

On the whole, however, the three thinkers offered a valuable, original critique of Marxism - a critique reflecting the specific historical experience of the Russian intelligentsia, including its persistent presentiment of the revolution. The results of their thinking about Marxism deserve to be known and assimilated by intellectual historians and by all those who want to have a better understanding of the greatest and most dangerous utopia of our century.

\section{References:}

Berdiaev N. Istoki i smysl russkogo kommunizma. Paris, YMCA Press, 1955.

Berdiaev N. K istorii psikhologii russkogo marksizma (1906). Saint-Petersburg, M.V. Pirozhkov, 1907.

Berdiaev N. Pravda sotsializma. Novoe religioznoe soznanie $i$ obshchestvennost'. Saint-Petersburg, M.V. Pirozhkov, 1907.

Berdiaev N. Socialism as Religion. A Revolution of the Spirit: Crisis of Value in Russia, 1890-1924 / ed. B. Glatzer Rosenthal and M. Bohachevsky- Chomiak. New York, Fordham University Press, 1990.

Bulgakov S. Ot marksizma к idealizmu: Sbornik statei (1896-1903). Saint-Petersburg, Obshchestvennaia pol'za, 1903.

Bulgakov S. Filosofiia khoziaistva. Moscow. 1990/

Calvez J.Y. La pensée de Karl Marx. Paris, Editions du Seuil, 1956.

Cunov H. Die Marxiche Gesschichts gessellshafts und Staatstheorie. Berlin, 1920.

Gerschenkron A. Economic Development in Russian Intellectual History. Economic Backwardness in Historical Perspective. New York, Praeger, 1965.

Herzen A. From the Other Shore and the Russian People and Socialism. London, Weidenfeld and Nicol son, 1956.

Ivanov-Razumnik R. Istoriia russkoi obshchestvennoi mysli, 2nd ed., 2 vols. Saint-Petersburg, M.M. Stasiulevich, 1908, vol. 2. 
Kelly G.A. Idealism. Politics and History Sources of Hegelian Thought. Cambridge, Cambridge University Press, 1969.

Kline L. 'Present', 'Past', and 'Future' as Categoreal Terms, and the 'Fallacy of the Actual Future.' Review of Metaphysics, 1986, Vol. 40, no. 2, pp. 215-235.

Kline L. The Use and Abuse of Hegel by Nietzsche and Marx. Hegel and His Critics: Philosophy in the Aftermath of Hegel / ed. William Desmond. Albany, New York, State University of New York Press, 1989, pp. 1 -34.

Lenin V.I. Collected Works, 45 vols. Moscow, Progress Publishers, 1960-70, vol. 5.

Marx K. Selected Writings / ed. D. McLellan. Oxford, Oxford University Press, 1985.

Marx K. Theories of Surplus Value, 2 vols. Moscow, Progress Publishers, 1969, Vol. 2.

Marx K., Engels F. Selected Works, 3 vols. Moscow, Progress Publishers, 1977, vol. 1.

Moore S. Marx on the Choice Between Socialism and Communism. Cambridge, MA and London, Harvard University Press, 1980.

Novgorodtsev P.I. Ob obshchestvennom ideale / ed A.V Sobolev. Moscow, Pravo, 1991.

Putnam G.F. Russian Ahernauws to Marxism. Christian Socialism and Idealistic Liberalism in TwentiethCentury Russia. Knoxville, TN, University of Tennessee Press, 1977.

Trotsky L. Literature and Revolution. Ann Arbor, MI, The University of Michigan Press, 1966.

Trotsky L. Terrorism and Communism. Westport, CT, Greenwood Press, 1986.

Trubetskoi E. Mirosozertsanie V. Solov'eva. 2 vols. Moscow, A I Mamontov, 1913, vol I.

Voegelin E. The Science of Politics. Chicago, IL, University of Chicago Press, 1987.

Walicki A. Kail Marx, ax Philosopher of Freedom. Critical Review, 1988, Vol. 2, no. 4, pp. 10-58.

Walicki A. Legal Philosophies of Russian Liberalism. Oxford, Clarendon Press, 1987.

Walicki A. Russia, Poland and Universal Regeneration. Notre Dame, IN, University of Notre Dame Press, 1989, pp. 39-69.

Walicki A. The Controversy Over Capitalism: Studies in the Social Philosophy of the Russian Populists, 2nd ed. Notre Dame, IN, University of Notre Dame Press, 1989. pp. 107-131.

Zenkovsky V.V. A History of Russian Philosophy / Trans. George L. Kline, 2 vols. London, Routledge and Kegan Paul, 1953, Vol. 1.

\section{About the Author:}

Andrzej Valitsky - Professor emeritus of the Polish Academy of Sciences and at the University of Notre Dame (Indiana, USA), full member of the Polish Academy of Sciences, the International Balzan Prize Laureate for Excellence in Science and Culture (1998); he also served as a visiting professor in various universities worldwide, including England, Australia, Austria, Denmark, USA, Switzerland, and Japan. 